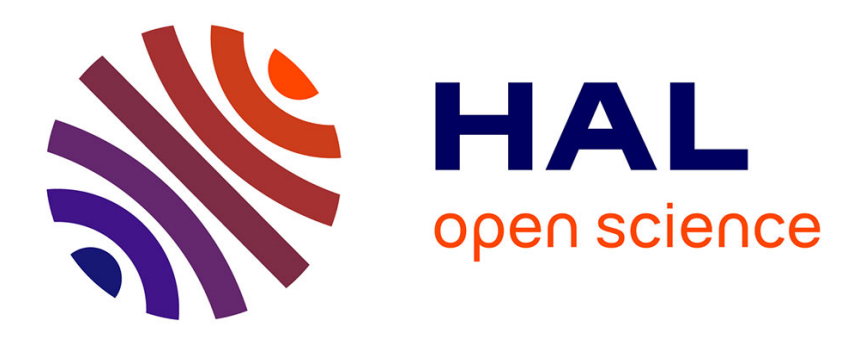

\title{
How to explore the 'spatialities' of avatars in a virtual world? Example of the project Magic Ring in Second Life
}

Jean-François Lucas

\section{To cite this version:}

Jean-François Lucas. How to explore the 'spatialities' of avatars in a virtual world? Example of the project Magic Ring in Second Life. At the edge of the rift, 2014. hal-02281059

\section{HAL Id: hal-02281059 \\ https://hal.science/hal-02281059}

Submitted on 7 Sep 2019

HAL is a multi-disciplinary open access archive for the deposit and dissemination of scientific research documents, whether they are published or not. The documents may come from teaching and research institutions in France or abroad, or from public or private research centers.
L'archive ouverte pluridisciplinaire HAL, est destinée au dépôt et à la diffusion de documents scientifiques de niveau recherche, publiés ou non, émanant des établissements d'enseignement et de recherche français ou étrangers, des laboratoires publics ou privés. 


\section{LUCAS Jean-François}

Sociologue (PhD), expert ville numérique / Smart City chez Chronos, cabinet d'études sociologiques, de conseil en innovation et de prospective.

Chercheur associé au Laboratoire de sociologie urbaine (LaSUR), École polytechnique fédérale de Lausanne (EPFL).

\section{How to explore the 'spatialities' of avatars in a virtual world? Example of the project Magic Ring in Second Life}

\footnotetext{
Attention, ce texte est un document de travail.

Il peut comporter des différences avec la version définitive du texte.
}

Merci de citer et de se référer à la version définitive :

LUCAS Jean-François, " How to explore the 'spatialities' of avatars in a virtual world? Example of the project Magic Ring in Second Life ", in Sue GREGORY, Paul JERRY, Nancy TAVARES-JONES (dir.), At the edge of the rift, Inter-Disciplinary Press, Oxford, UK, 2014, pp.65-77 


\title{
How to Explore the 'Spatialities' of Avatars in a Virtual World? Example of the Project Magic Ring in Second Life
}

\author{
Lucas Jean-François
}

\begin{abstract}
This chapter presents a project developed in a study about the narrative dimension of the immersion process in the virtual world of Second Life. This digital universe is not usual because users can build the digital environment themselves, that means that they design and shape the Second Life's space. In order to understand the impact of the space on the avatars behaviour, I developed a tracking tool, called the 'Magic Ring,' which collects millions of 'quali-quantitative' data. This name means that they are very accurate data in big quantity (millions of data), which allow the researcher to choose between a qualitative approach or a quantitative one. This chapter focuses on project genesis to explain how the idea to develop a tracker came to us. Firstly, I present Second Life by emphasising the possibility for the user to build the three dimensional world. Secondly, I deliver contextualised overview of our immersion study, especially about the narrative dimension of this process. I explain I used the concept of 'spatiality,' and I define it, to understand the link between the shape of the space and the avatars behaviour in the virtual world. I also present the limitations encountered in this study and the need to develop an appropriate method to solve our problematic. Before explaining how the Magic Ring works, I describe two others projects that have inspired it. Finally, I briefly evoke some results, explaining that avatars often return to the same places, identified as 'hotspots,' and I discuss the theoretical possibilities a device like the Magic Ring and quali-quantitative data open.
\end{abstract}

Key Words: Magic Ring, tracking tool, tracker, virtual world, Second Life, avatar, avatar behaviour, spatiality, methodology, ethnography, Big Data, qualiquantitative data.

$* * * * *$

\section{The Virtual World of Second Life}

Second Life is a persistent multi-user three dimension virtual world accessible on the Internet. A user can move and communicate into this world through an avatar, his/her representation on the screen. No scenario determines the conduct and the progress of the Second Life user, which means that everyone is, a priori, free to make 'whatever he wants.' In other words, each one can explore the world as he wishes without having to follow a storyline in a video game and complete missions or quests to advance therein.

The lack of scenario is linked to the editor's willingness (Linden Lab) of allowing users to build the environment they experience. ${ }^{1}$ In this sense, Second 
Life has been designed as a blank space in which users can construct, organise and animate $^{2}$ three dimensional (3D) objects. That means that Second Life users, except for certain areas designed and managed by the editor, produce all of the 3D objects and environments seen this virtual world; that is why I consider Second Life as a 'Virtual World of Content Creation' (VWCC). ${ }^{3}$ On this point, Tom Boellstorff stated that less than of one per cent of the objects he found in the virtual world during his fieldwork were created by Linden Lab. ${ }^{4}$ Thus, its evolution is directly affected by how avatars produce the digital environment ${ }^{5}$ and their practices and behaviour are particularly interesting to study because they reflect their aspirations and the possibilities of this world: doing business, meeting people, having fun, playing online, visiting many and miscellaneous territories, educating, prototyping, etc.

\section{The Role of Space in the Avatar's Behaviour}

In my doctoral thesis, ${ }^{6}$ I focused on the phenomenon of immersion within virtual worlds, especially in Second Life. After Janet Murray, I view the immersion process as the fact of experiencing 'the sensation of being surrounded by a completely other reality that takes over all of our attention, our whole perceptual apparatus. ${ }^{7}$ In other words, I consider that

immersion occurs when one gazes at a painting, listens to music, is lost in a book or absorbed in a game of chess, so much that he ceases to perceive the museum or the sounds of the street, forgets the events happening in the real world, and suspends his knowledge of its laws.

When someone is immersed in a virtual world, he is 'taken' in, he is 'submerged' into and he has the sensation of being 'inside.' But, I should point out that I consider immersion more as a process than a state, which means immersion can be spread out in time. To understand how the immersive process takes place in Second Life, I studied it through three dimensions:

- $\quad$ The perceptive dimension, which defines the way or ways used to 'bring the viewer into an imaginary space by creating the material conditions of impaired perception. ${ }^{9}$

- The narrative (or fictional) dimension, which characterises how users are engaged in a fiction in the virtual world.

- The social dimension, that is to say, the ways in which the user is 'caught' in the world when he 'belongs to,' he takes 'part of' or he is a 'member' of a group. 
To study these three dimensions of the immersive process, I delimited our fieldwork to cities in Second Life.

The space of SL is a Cartesian system where each territory, called an 'island,' is a square of 256 meters. ${ }^{10}$ Their number nearly reaches 26000 and the Second Life's territory size is evaluated as $1715.34 \mathrm{~km}^{2},{ }^{11}$ which is equivalent to almost 16 times the size of Paris or 1.3 times the one of Los Angeles. Users can buy, rent or just visit those islands, and they also can build cities on it.

The city is an interesting pattern to study diversity of people practices, because you can observe 'plurality, coexistence and simultaneity in the urban patterns, ways of living urban life. ${ }^{12}$ It is a good way to study social phenomena in their forms, not in their content, according to Simmel. ${ }^{13}$ In other words, I focused on how they act into the virtual world and not why they act the way they do. So, I analysed how avatars move, how they regroup, how they interact, etc., in the Second Life cities. I sought to understand how avatars are acted, engaged and immersed in a world that has no scenario and how the city can produce a scenario.

Firstly, to understand how someone is immersed in a fictional or narrative story in Second Life, I looked at the user ability to forge one or more identities through the avatar. ${ }^{14}$ I also studied the notion of 'attachment,' 15 i.e. the relationship between the user and the avatar and the affection that characterises it.

To complete this avatar-centred approach, I analysed the role of space in the possibility of creating a fiction and of modifying the avatars behaviour. In other words, I questioned the urban shape of cities as a possible narrative architecture. Compared to video games, this problematic is particularly relevant because there are no predefined goals in Second Life and avatars build, organise and shape the world according to their own desires. So, the in-world's game design relates to a coupling between the technical features of the device (the virtual world's characteristics, the interface, etc.) and the avatars creation.

To understand the link between the shape of the space and the avatars' behaviour in the virtual world, I studied their 'spatialities. ${ }^{16}$ For the French geographer Michel Lussault, 'spatiality' is a concept that allows understanding the 'junction' between 'spaces (too often reduced to their physical forms)' and social practices. ${ }^{17}$ Spatiality represents 'all practical relations of individuals and groups to the space, ${ }^{18}$ this means that the actor does not act on space, but with the space. ${ }^{19}$

\section{How to Follow Thousands of Avatars at the Same Time?}

To analyse the spatialities of avatars in Second Life, I first resorted to the virtual anthropology as defined by Tom Boellstorff. ${ }^{20}$ Thus, I focused on the practices of people within Second Life and I choose to exclude their daily lives when they are not connected to the virtual world.

Our first step was to make observations, as a 'complete observer' ${ }^{21}$ or as a 'peripheral member. ${ }^{22}$ During several weeks I observed avatars or groups to understand their spatial behaviour in cities. Results of this first study showed that 
avatars are often unmoving in a same geographical area. To complete these results, I gathered narrative of avatars' experiences and I conducted interviews with them in Second Life. In part, I obtained the same results: Some people even affirmed that it was 'stupid to study how avatars move in Second Life when nobody moves!'

Nevertheless, I obtained some interesting trails to explore, since some interviewees reported that they often return to the same places in the virtual world. I wanted to study this point more precisely because the immobility of the avatars does not mean that they are inactive. In fact, they can communicate through various channels (public chat, private messages, etc.) while the digital body does not move. From this point, I sought to know how often and why avatars come at the same place and I tried to determine role of the space in this phenomenon.

I had two choices to study this question. The first was to follow avatars in the virtual world and identify the frequency of the areas visited. The disadvantage of this method is that I could not know if and when an avatar would return to the same territory. The second was to stay on some territories to note the presence and the name of the avatars, but the limitations of this method remain numerous. Additionally, I wanted to observe the practices of many people in many territories at the same time, which required collecting data on the avatars' mobility and their interactions with space (frequenting, number of avatars in a group, avatar's way of travelling, use of space, etc.). Consequently, these choices involved the production of a new method of observation.

\section{Related Work}

In 2007, Nick Yee and Jeremy Bailenson conducted a study about the nonverbal language in Second Life. ${ }^{23}$ They developed a tracker, recovering data about avatars in the virtual world: last name, first name and the position of the avatar (spatial coordinates like ' $x, y$ '), the number of avatars in a defined area (16 avatars maximum within a radius of 20 meters), etc. This tracker is attached to an avatar steered by a researcher, which has to trigger it to get data when he is close to a group of at least two avatars interacting. With this method, six research assistants were employed for a month and a half to obtain a sufficient amount of data. ${ }^{24}$

In another project, Friedman and his team developed bots to study avatar behaviour in Second Life when they are interacting. ${ }^{25}$ If a researcher can control bots, they also can move on their own initiative. In such a case, they 'select a random direction and start walking in that direction, until it either reaches an obstacle (such as a wall) or the target, ${ }^{, 6}$ and when it detects one or more avatars

it stops and carries out its social task (...) when it encounters other avatars it greets them using their name. The bot can also play a large range of approximately 50 pre-recorded animations. ${ }^{27}$ 
Although bots 'look a bit drunk' researchers conceded they still are 'a great way to get data.' 28

\section{The Magic Ring: A Tracker in Second Life}

Unlike Yee's project, I excluded the idea of a tracker that would need to be triggered in the virtual world because this method takes considerable time for a single researcher. In addition, it is preferable to follow avatars around the virtual world in order to study their spatial behaviour, which implies a different tool from a robot.

To meet planned need, I developed a tracker intended to be worn by avatars themselves. This tracker is a ring in the virtual world (Figure 1) and I called it the 'Magic Ring.'

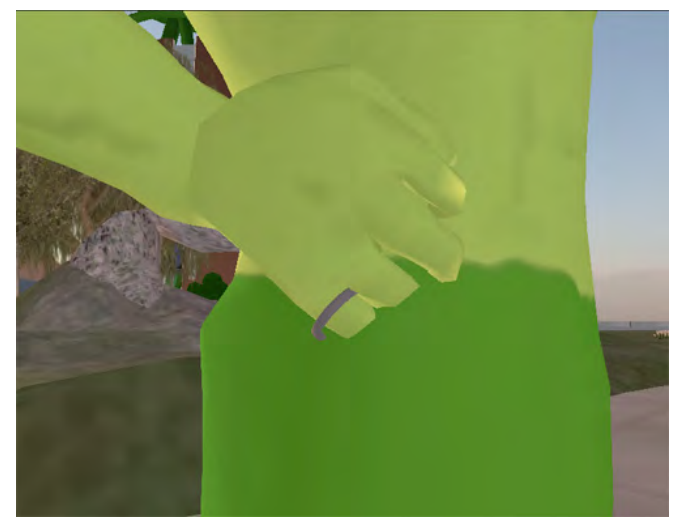

Figure 1: The Magic Ring on an avatar’s finger in Second Life. (C) 2010, Lucas Jean-François.

To be active, or to get data, the tracker needs to be attached to an avatar (or an avatar needs to 'wear' it). That means that Second Life users must accept to participate to our study and to be followed when they are connected. It also means that it necessary to have unique tracker to each avatar, which is easy to do as it can be duplicated.

This tracker contains a script that measures twenty-nine variables every five seconds (for each avatar) that are directly sent to a secure database. These variables correspond to two types of data: some about the avatar (first name, last name, posture - sitting, standing - travelling mode - still, walking, running or flying etc.) the others about the territory (territory name, position of the avatar on the territory, number of avatars around the one who wears the tracker in a twenty meters perimeter, etc.). 
Avatars can obtain the Magic Ring from automatic distributors (Figure 2) spread over many Second Life areas. When an avatar clicks on a distributor, he gets a Magic Ring and an information sheet about the options and features of the tracker as well as all of the study conditions. This document also includes a code of ethics and responsibilities, which is inspired by the code of ethics of the French Sociological Association (AFS), and the user's rights conferred by the French National Commission of Informatics and Liberties (CNIL).

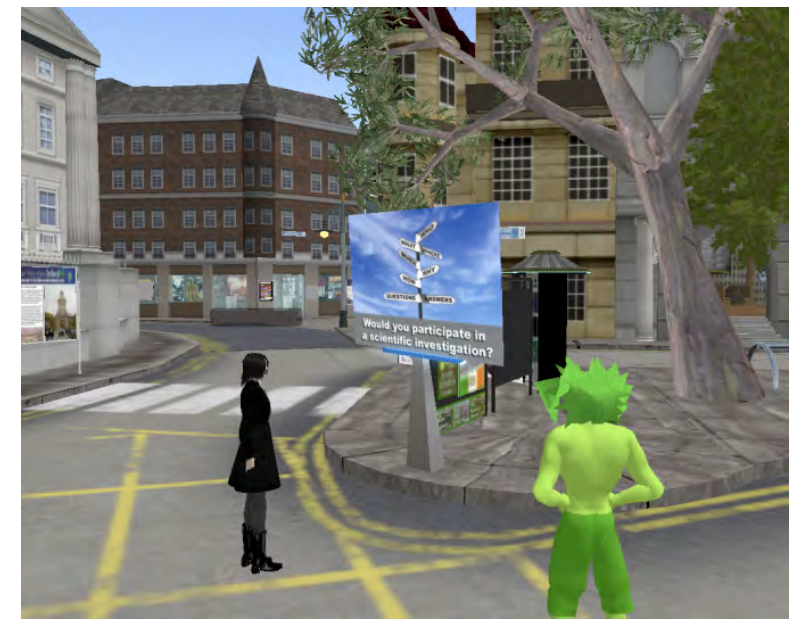

Figure 2: Two avatars in front of a Magic Ring distributor. (C) 2010, Lucas Jean-François.

In six months, from April 6 to October 6, 2011, two hundred and eleven avatars participated in our study. I collected nearly three million geographical coordinate points $(x-y-z)$, that is to say a total of nearly ninety million data points, each comprised of twenty-nine variables.

\section{Results and Perspectives}

The main interest of the Magic Ring is to follow hundreds of avatars in the same time at different places with accuracy, when the researcher is restricted to study small groups of avatars or small samples of territories with ethnography. Another interesting feature was to study practices of occasional users. For example, some avatars are only connected once a month in the virtual world. The benefit of the Magic Ring is to not have to keep a close watch on the users' connections as they keep the tracker with them.

With the data obtained, I analysed many aspects of spatial behaviour in Second Life. For example, I examined the visits frequency for a same territory for a lot of 
avatars and I compared the paths followed each time, for each of them. The figure 3 shows an analysis of the spatial behaviour of avatar $8^{29}$ on a specific island (represented by a square with a side of 256 pixels). On the left, I can see his position on the island for all of its connections. In the centre, the gRadius value indicates the presence of others avatars (here, avatar 8 was always alone on this territory) and, on the right, I can see when he came on this island from April 6 to October 6, 2011.

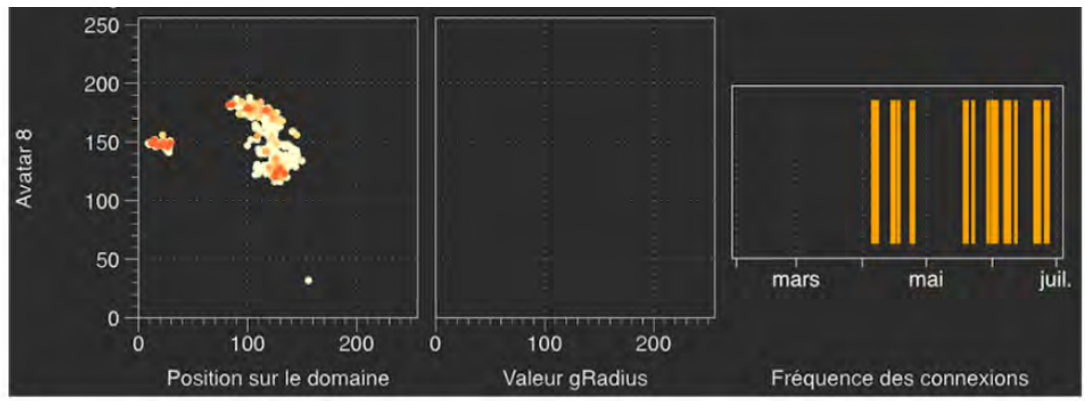

Figure 3: The spatial behaviour of avatar 8 on an island. The more the avatar is at the same place, the more the dot is red. (c) 2012, Lucas Jean-François.

I also examined the spatial distribution of people within a same territory during six months (Figure 4), which allowed us to identify 'hotspots.' A hotspot can be defined as an area that is often occupied and which runs regular activities. So, I compared different hotspots, trying to understand urban common features that would explain why and how avatars often return to the same place. Our main conclusion was that a singular 'atmosphere' and a coupling between 'content' and a good 'container' characterise these spaces. ${ }^{30}$

Some of these conclusions can be obtained by other methods (ethnography, interviews), but none of them allow us to compare such large amounts of data with a high degree of precision.

In this chapter I could have included a more complete description of our results, explaining how they influenced our study about the immersive process even if it would have required a more complete description of our overall work. However, I chose to focus on the opportunities created by this kind of project in order to question the theoretical developments that can be made. A tool like the Magic Ring does not just redefine the size and scales of databases by creating huge databases (Big Data), it changes the relationship I have with them since 'I no longer have to choose between data size and depth. ${ }^{, 31}$ 


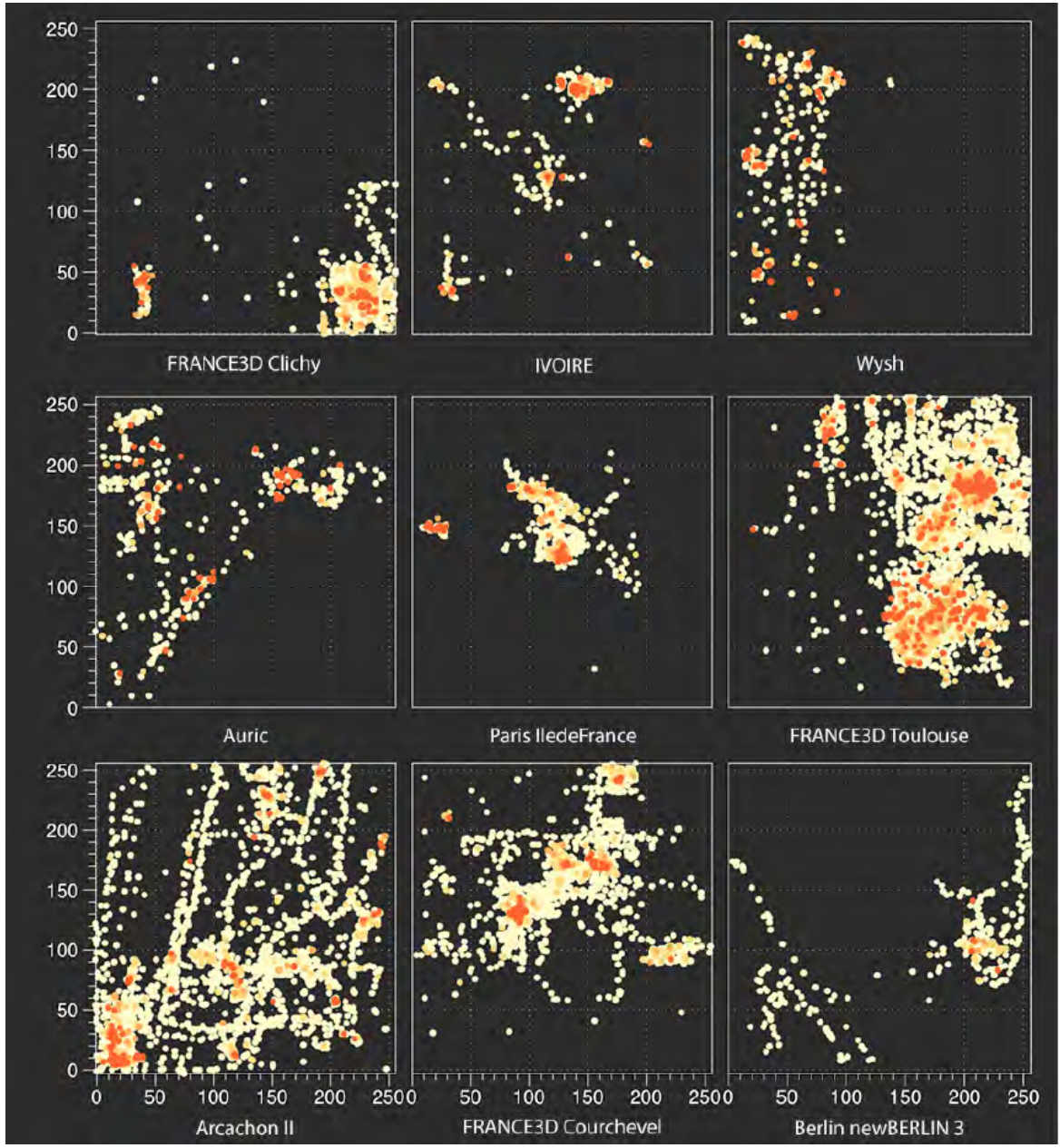

Figure 4: An example of a matrix of avatars' spatial behaviour in Second Life. Squares represent different islands and dots represent avatars position. (C) 2012, Lucas Jean-François.

Through a classical sociological approach, I could have analysed the spatial practices of some avatars and tried to verify the results for a larger sample. I would have gone from micro to macro, or vice-versa. Our approach is different because it involved recovering the largest possible amount of data without finely defining selection criteria before the work begins. In other words, the researcher is no longer subjected to the draconian choice between a qualitative and a quantitative 
method. Now, he can work with 'quali-quantitative' data, that is to say, very accurate data, in large quantities, for a very large sample; such as the ones I collected with the Magic Ring.

With these data and data visualisation software, I have created 'entities' which allow us to explore data from avatars and data from territories in the same time without any distinction between these kinds of data. For Bruno Latour and his colleagues, this kind of hybrid entity is a 'monad,' that is

a highly specific point of view - this or that entity - on all the other entities present in the dataset (...), a point of view on all the other entities taken severally and not as a totality. ${ }^{32}$

This approach allowed me to develop an analysis of spatial practices 'surfing from document to document, encountering people and exploring communities without ever changing level that I wish to use as an occasion to rethink social theory. 33

To conclude, practically, such research provides an example of a tool that researchers can produce to study many aspects of avatars behaviour in a virtual world. If I have evoked only some results, one can imagine that there are many others possibilities by crosschecking data in different ways to produce others analysis. Furthermore, a tool like the Magic Ring can redefine the type of studies I produce: why not consider following many avatars during one or few years with high precision? Theoretically, such research may provide us with new perspectives about how to do and think about sociology, as Bruno Latour does by bringing up to date Tarde's sociology.

\section{Notes}

${ }^{1}$ To read more about this point refer to: Wagner James Au, The Making of Second Life: Notes from the New World (New York: Collins, 2008), 24.

2 Second Life has its own scripting language, the Linden Scripting Language (LSL).

${ }^{3}$ In French: 'Monde Virtuel de Création de Contenu' (MVCC). Jean-François Lucas, 'Interactions et Réalité Mixte dans la Ville Hybride', HyperUrbain 3 : Villes Hybrides et Enjeux de L'aménagement des Urbanités Numérique, Actes de Colloque HyperUrbain.3, ed. Zreik Khaldoun (Paris: Europia Production, 2012).

${ }^{4}$ Tom Boellstorff, Coming of Age of Second Life: An Anthropologist Explores the Virtually Human (Princeton University Press, 2010), 97.

${ }^{5}$ Mary C. Whitton, 'Making Virtual Environments Compelling', Communications of the ACM 46, No. 7 (2003): 40-47. 
${ }^{6}$ Jean-François Lucas, 'De l’Immersion à l'Habiter dans les Mondes Virtuels. Le Cas des Villes dans Second Life' (PhD diss., European University of Brittany, Rennes 2, 2013).

7 Janet H. Murray, Hamlet on the Holodeck: The Future of Narrative in Cyberspace (Cambridge, MA: The MIT Press, 1997), 98.

8 Dominic Arsenault, 'Dark Waters: Spotlight on Immersion', Game On North America 2005 Conference Proceedings (2005): 51.

${ }^{9}$ Dominique Boullier, 'Le Web Immersif', Quaderni 66 (2008): 67-80.

10 For a more comprehensive description of the organisation of Second Life territories: http://wiki.secondlife.com/wiki/Land.

${ }^{11}$ Since 2010, this figure is down: http://gridsurvey.com/index.php.

${ }^{12}$ Henri Lefebvre, Le Droit à la Ville, $3^{\text {rd }}$ Edition (Paris: Anthropos, Economica, 2009).

${ }^{13}$ Georg Simmel, Sociologie et Epistémologie (Paris: PUF, Sociologies, 1981).

${ }^{14}$ Sherry Turkle, Life on the Screen: Identity in the Age of the Internet (New York: Simon and Schuster, 1995); Patrice Flichy, 'Le Corps dans L'espace Numérique', Esprit 343 (2009): 163-174; Fanny Georges, Identités Virtuelles. Les Profils Utilisateur du Web 2.0 (Paris: Collection L>P : QuestionsThéoriques, 2010).

${ }^{15}$ Dominic Arsenault and Martin Picard, 'Le Jeu Vidéo entre Dépendance et Plaisir Immersive: Les Trois Forms D’immersion Vidéoludique’, Actes de Colloque, HomoLudens, Le Jeu Video: Un Phénomène Social Massivement Pratiqué (Congrès de l'ACFAS, 2008).

16 Michel Lussault, L'Homme Spatial: La Construction Sociale de l'Espace Humain (Paris: Les Éditions du Seuil, 2007).

${ }^{17}$ Ibid., 264.

${ }^{18}$ Michel Lussault, 'La Mobilité comme Evénement', Les Sens du Mouvement: Modernité et Mobilités dans les Sociétés Urbaines Contemporaines, eds. Sylvain Allemand, François Ascher and Jacques Lévy (Paris: Belin, Colloque de Cerisy/Institut Pour la Ville en Movement, 2004), 111.

${ }^{19}$ Lussault, L'Homme Spatial, 147 and 181.

${ }^{20}$ Boellstorff, Coming of Age of Second Life.

${ }^{21}$ Raymond L. Gold, 'Roles in Sociological Field Observations', Social Forces 36, No. 3 (1958): 217-223.

${ }^{22}$ Patricia Adler and Peter Adler, Membership Roles in Field Research (Qualitative Research Methods) (Newbury Park, CA: Sage Publications, 1987).

${ }^{23}$ Nicholas Yee et al., 'The Unbearable Likeness of Being Digital: The Persistence of Nonverbal Social Norms in Online Virtual Environments', Cyberpsychology and Behavior 10, No. 1 (2007): 115-121.

${ }^{24}$ Ibid., 117.

${ }^{25}$ Doron Friedman, Anthony Steed and Mel Staler, 'Spatial Social Behavior in Second Life', 7th International Working Conference, IVA 2007, Paris, France, 
September 17-19, 2007, Proceedings, eds. Catherine Pelachaud, Jean-Claude Martin, Elisabeth Andre, Gerard Chollet and Kostas Karpouzis (Heidelberg: Springer-Verlag, 2007), 252-264.

${ }^{26}$ Ibid., 254.

${ }^{27}$ Friedman, Steed and Slater, Spatial Social Behavior in Second Life, 254.

${ }^{28}$ Tom Somonite, 'Anti-Social Bot Invades Second Lifers' Personal Space', NewScientist Tech, 2 November 2007, http://bit.ly/1qN0Ai2.

${ }^{29}$ All of our results are anonymous.

${ }^{30}$ Dominique Boullier, La Ville-Evénement: Foules et Publics Urbains (Paris: PUF, La Ville en Débat, 2010); See more: Lucas, 'De l'Immersion à l'Habiter dans les Mondes Virtuels', 289-306.

${ }^{31}$ Lev Manovich, 'Trending: The Promises and the Challenges of Big Social Data', in Debates in the Digital Humanities, ed. Matthew Gold (The University of Minnesota Press, 2012), 466.

32 Bruno Latour, Pablo Jensen, Tommaso Venturini, Sébastian Grauwin and Dominique Boullier, 'The Whole Is Always Smaller than Its Parts: A Digital Test of Gabriel Tarde’s Monads’, British Journal of Sociology 63, No. 4 (2012): 598.

${ }^{33}$ Ibid., 598.

\section{Bibliography}

Adler, Patricia, and Peter Adler. Membership Roles in Field Research (Qualitative Research Methods). Newbury Park, CA: Sage Publications, 1987.

Arsenault, Dominic. 'Dark Waters: Spotlight on Immersion'. Game On North America 2005 Conference Proceedings (2005): 50-52.

Arsenault, Dominic, and Martin Picard. 'Le Jeu Vidéo entre Dépendance et Plaisir Immersive: Les Trois Forms D’immersion Vidéoludique'. Actes de Colloque, HomoLudens, Le Jeu Video: Un Phénomène Social Massivement Pratiqué. Congrès de l'ACFAS, 2008.

Au, Wagner James. The Making of Second Life: Notes from the New World. New York: Collins, 2008.

Boellstorff, Tom. Coming of Age of Second Life: An Anthropologist Explores the Virtually Human. Princeton University Press, 2010.

Boullier, Dominique. 'Le Web Immersif'. Quaderni 66 (2008): 67-80. 
Débat, 2010.

Flichy, Patrice. 'Le Corps dans L’espace Numérique’. Esprit 343 (2009): 163-174.

Friedman Doron, Anthony Steed, and Mel Staler. 'Spatial Social Behavior in Second Life'. In Intelligent Virtual Agents: 7th International Working Conference, IVA 2007, Paris, France, September 17-19, 2007, Proceedings, edited by Catherine Pelachaud, Jean-Claude Martin, Elisabeth Andre, Gerard Chollet and Kostas Karpouzis, 252-264. Heidelberg: Springer-Verlag, 2007.

Georges, Fanny. Identités Virtuelles. Les Profils Utilisateur du Web 2.0. Paris: Collection L>P : QuestionsThéoriques, 2010.

Gold, Raymond. 'Roles in Sociological Field Observations'. Social Forces 36, No. 3 (1958): 217-223.

Latour, Bruno, Pablo Jensen, Tommaso Venturini, Sébastian Grauwin, and Dominique Boullier. 'The Whole Is Always Smaller than Its Parts: A Digital Test of Gabriel Tarde's Monads'. British Journal of Sociology 63, No. 4 (2012): 591615.

Lefebvre, Henri. Le Droit à la Ville. $3^{\text {rd }}$ Edition. Paris: Anthropos, Economica, 2009.

Lucas, Jean-François. 'Interactions et Réalité Mixte dans la Ville Hybride'. HyperUrbain 3: Villes Hybrides et Enjeux de L'aménagement des Urbanités Numérique, Actes de Colloque HyperUrbain.3, edited by Zreik Khaldoun, 47-63. Paris: Europia Production, 2012.

—. 'De l'Immersion à l'Habiter dans les Mondes Virtuels. Le Cas des Villes dans Second Life'. PhD Dissertation, European University of Brittany, Rennes 2, 2013.

Lussault, Michel. 'La Mobilité comme Evénement'. Les Sens du Mouvement: Modernité et Mobilités dans les Sociétés Urbaines Contemporaines, edited by Sylvain Allemand and François Ascher and Jacques Lévy, 109-116. Paris: Belin, Colloque de Cerisy/Institut Pour la Ville en Movement, 2004.

- L'Homme Spatial: La Construction Sociale de l'Espace Humain. Paris: Les Éditions du Seuil, 2007. 
Murray, Janet H. Hamlet on the Holodeck: The Future of Narrative in Cyberspace. Cambridge, MA: The MIT Press, 1997.

Simmel, Georg. Sociologie et Epistémologie. Paris: PUF, Sociologies, 1981.

Turkle, Sherry. Life on the Screen: Identity in the Age of the Internet. New York: Simon and Schuster, 1995.

Whitton, Mary C. 'Making Virtual Environments Compelling'. Communications of the ACM 46, No. 7 (2003): 40-47.

Yee, Nicholas, Jeremy Bailenson, Mark Urbanek, Francis Chang, and Dan Merget. 'The Unbearable Likeness of Being Digital: The Persistence of Nonverbal Social Norms in Online Virtual Environments'. Cyberpsychology and Behavior 10, No. 1 (2007): 115-121.

Lucas Jean-François, $\mathrm{PhD}$ in sociology, is in charge of studies and projects of the Chair of Research and Training 'Modelling of Imaginary, Innovation and Creation' at Telecom ParisTech, Paris, France. He is a member of the LTCI (Laboratory for Communication and Processing of Information) is a joint research lab (UMR 5141) between the CNRS (Centre National de la Recherche Scientifique) and Telecom Paristech. 